\title{
Dust in the Wind: How Climate Variables and Volcanic Dust Affect Rates of Tooth Wear in Central American Howling Monkeys
}

\author{
Jackson P. Spradley, ${ }^{*}$ Kenneth E. Glander, and Richard F. Kay \\ Department of Evolutionary Anthropology, Duke University, Durham NC \\ KEY WORDS Platyrrhini; volcanic ash; dental ageing; habitat variation
}

\begin{abstract}
Objectives: Two factors have been considered important contributors to tooth wear: dietary abrasives in plant foods themselves and mineral particles adhering to ingested food. Each factor limits the functional life of teeth. Cross-population studies of wear rates in a single species living in different habitats may point to the relative contributions of each factor.

Materials and Methods: We examine macroscopic dental wear in populations of Alouatta palliata (Gray, 1849) from Costa Rica (115 specimens), Panama (19), and Nicaragua (56). The sites differ in mean annual precipitation, with the Panamanian sites receiving more than twice the precipitation of those in Costa Rica or Nicaragua $(\sim 3,500 \mathrm{~mm}$ vs. $\sim 1,500 \mathrm{~mm})$. Additionally, many of the Nicaraguan specimens were collected downwind of active plinian volcanoes. Molar wear is expressed as the ratio of exposed dentin area to tooth area; premolar wear was scored using a ranking system.

Results: Despite substantial variation in environmental variables and the added presence of ash in some environments, molar wear rates do not differ significantly among the populations. Premolar wear, however, is greater in individuals collected downwind from active volcanoes compared with those living in environments that did not experience ash-fall.

Discussion: Volcanic ash seems to be an important contributor to anterior tooth wear but less so in molar wear. That wear is not found uniformly across the tooth row may be related to malformation in the premolars due to fluorosis. A surge of fluoride accompanying the volcanic ash may differentially affect the premolars as the molars fully mineralize early in the life of Alouatta. Am J Phys Anthropol 000:000-000, 2015. ( $) 2015$ Wiley Periodicals, Inc.
\end{abstract}

Studies of dental morphology and tooth wear play a key role in reconstructing the paleoecology of fossil species and populations. As it has for many years in human studies (Molnar, 1971; Broca, 1879; Goldstein, 1948; Murphy, 1959; Walker, 1978; Lovejoy, 1985; McKee and Molnar, 1988; Larsen, 1995), dental wear has emerged as a useful adjunct to morphological analysis for inferring hominin and non-human primate dietary habits (Grine et al., 1986; Grine and Kay, 1988; Teaford and Runestad, 1992), habitat preference and seasonal changes in diet (Walker et al., 1978; Nussey et al., 2007), chronological age (Froehlich et al., 1981; Hewison et al., 1999; Ingicco et al., 2012) and demography (Phillips-Conroy et al., 2000; King et al., 2005; Romero and Timm, 2013). Many studies of tooth wear in nonhuman primates and other mammals have looked to explain variations in the rates of tooth wear in different populations or species as a consequence of variations in the mechanical properties of the foods consumed (toughness, hardness, etc.) (Kay, 1981; Yamashita, 1998; Cuozzo and Sauther, 2006), the presence of silica bodies in the food (Strömberg, 2006; Walker et al., 1978), the presence of environmental exogenous grit that adheres to ingested food (Ungar, 1995; Sanson et al., 2007; Lucas et al., 2013; Damuth and Janis, 2014; Galbany et al., 2014; Madden, 2015), or a combination of those factors (Kay et al., 1999; Williams and Kay, 1999). Proxies for estimating tooth wear have varied and include ordinal ranking of wear (Lovejoy, 1985; McKee and Molnar, 1988) the percentage of dentin exposed on the tooth crown (Murphy, 1959; Walker, 1978; Tomenchuk and Mayhall,
1979; Molnar et al., 1983; Teaford, 1983; Fortelius, 1985; Hillson, 1987; Morse et al., 2013) the height of the cheektooth crown (Fortelius and Solounias, 2000), and tooth loss from excessive wear or caries (Xhonga et al., 1972; Smith et al., 1977; Molnar et al., 1983; Teaford and Oyen, 1989). Studies of tooth wear typically concentrate on a single cheek tooth but these studies occasionally are extended to the entire post-canine tooth row (Campbell, 1939; Davies and Pederson, 1955; Froehlich et al., 1981; Fortelius, 1985; Hillson, 1987; Cuozzo and Sauther, 2006). Similarly, studies on the effects of the physical properties of food or exogenous grit on wear rates have involved human populations and a few wild or laboratory mammalian populations (Molnar, 1971; Hinton, 1981; Kay and Covert, 1983;

Additional Supporting Information may be found in the online version of this article.

Grant sponsor: US National Science Foundation Frontiers in Earth System Dynamics grant; Grant number: EAR-1338694; Grant sponsor: NSF; Grant number: BCS-1232534.

*Correspondence to: Jackson P. Spradley, Department of Evolutionary
Anthropology, Duke University, Durham NC. E-mail: jps46@duke.edu

Received 11 November 2014; revised 31 July 2015; accepted 11 September 2015

DOI: 10.1002/ajpa.22877

Published online 00 Month 2015 in Wiley Online Library

(wileyonlinelibrary.com). 
Teaford and Tylenda, 1991; Teaford and Glander, 1996; Phillips-Conroy et al., 2000; Yamada, 2012; Damuth and Janis, 2014).

It is hypothesized that tooth wear in life directly affects inclusive fitness. Primates and most other mammals are limited to two sets of teeth. As these teeth do not repair themselves, their functionality declines with wear, limiting the ability to gain sufficient energy to bear and raise offspring and thus limiting lifespan (King et al., 2005). Morphological responses in evolutionary time that allow prolongation of function have included changes in enamel thickness, enamel prism structure, and (in herbivores) increasing crown height (Rensberger and Von Koenigswald, 1980; Janis, 1988; Lucas et al., 2008; Pampush et al., 2013).

Many factors influence tooth wear (Janis and Fortelius, 1988), but two factors are most often mentioned: (1) the endogenous physical properties of ingested foods and (2) the exogenous grit adhering to them.

With respect to endogenous sources of wear, silica phytoliths in plant foods are commonly mentioned materials within herbivorous foods that could accelerate tooth wear and lead to early dental senescence. In particular, herbivorous species encounter higher wear rates when they ingest a higher percentage of endogenous dietary silica, and in turn have higher cheek-tooth tooth crowns (as measured by the hypsodonty index) (Hummel et al., 2011). As silica phytoliths are generally more abundant (as a percentage of dry weight) in grasses than in browse (Piperno, 1988; Hodson et al., 2005), this result has been interpreted as a dietary signal for grass eating. In a study of Japanese sika deer, Yamada (2012) found a strong positive correlation between wear rate and the percentage of grass in the diet. Walker et al. (1978) reported similar findings comparing two species of African hyraxes.

Though the relationship between grass eating and microwear is well established, the causal mechanism behind this relationship remains a topic of debate. Specifically, the question is whether silica phytoliths are hard enough to scratch enamel. Studies by Sanson et al. (2007) and Lucas et al. (2013) suggested that plant phytoliths are too soft to scratch tooth enamel, and that ingested quartz dust was the more likely cause of microwear scratches. However, in a critique of Lucas et al. (2013), Rabenold and Pearson (2014) claimed that the analysis of Lucas et al. failed to take into account the specific physical properties of phytoliths, thereby possibly underestimating the hardness of phytoliths. The debate is thus a question of the relative contributions of phytoliths and exogenous grit to the rate of tooth wear. While we do not address this question directly, the study of wear rates in wild populations is likely to inform the discussion.

Other endogenous food properties may also have an effect on wear patterns. Earlier studies reported differences in the molar microwear (i.e., the microscopic pattern of wear on occluding tooth surfaces) between hard-object specialists and folivorous species (Teaford, 1985; Ungar, 1998; Scott et al., 2006). Likewise there are instances where the strepsirrhine primate Lemur catta, when feeding on particularly tough and abrasive foods (legume pods), produces exceptionally heavy tooth wear (Cuozzo and Sauther, 2006). In each of these cases, it is not clear whether silica or some other abrasive material is the source of the wear.

Another source of endogenous wear is that of attrition, the loss of enamel due to mechanical forces between opposing teeth. The impact of attrition on wear during chewing is a commonly recognized phenomenon (Teaford and Walker, 1984; Teaford and Runestad, 1992; Lucas et al., 2013) and indeed this process has even been shown to occur in utero in guinea pigs (Ainamo, 1977) in the complete absence of any external source of grit or dietary abrasive. While differences can and do occur in the physical properties of ingested food, there are no obvious reasons to expect that any differences in attrition among populations of the same species.

A second commonly mentioned source of tooth wear is exogenous particles (grit) adhering to foods. Many sources of grit have been mentioned, especially including soil minerals adhering to foods and grit introduced by food preparation techniques (Ruffer, 1920; Barrett, 1958; Dahlberg, 1963; Storey, 1976). Quartz has been mentioned as one such common material. Volcanic ash also has been proposed as an important source of dust particles producing wear with possible effects on evolutionary trends towards hypsodonty among herbivores. Dust, rather than silica phytoliths, may be an important selective agent for the evolution of primate hypsodonty, at least in South America where an intermittent rain of volcanic dust occurred for millions of years over the southern parts of the continent (Kay et al., 1999; Dunn et al., 2009). If abrasive volcanic ash (including glass shards and other volcanic minerals) dusted the ingested foods, the effects would be particularly marked in herbivores feeding on any type of vegetation whether at ground level or in the trees. Smith et al. (1977) observed this very effect in primate species in Nicaragua that lived downwind from an active volcano. They noted that individuals from these populations suffered from excessive tooth wear and other dental pathologies. Two species of Oligocene and Miocene platyrrhine primates, Branisella and Mazzonicebus were primarily adapted for frugivory and seed-eating, respectively, so a grass-eating effect would not be expected. Nevertheless, each has relatively hyposdont teeth compared with extant platyrrhines (Kay et al., 2002; Kay, 2010), suggesting either some degree of terrestriality or other exposure to exogenous dust.

In most studies of tooth wear it is impossible to determine which contributes more to wear - the material properties of the forage itself or the exogenous grit adhering to food. In comparative studies, differences in crown heights of the cheek teeth of arboreal versus terrestrial mammals have been noted. This seems to suggest that terrestrial foragers incorporate more grit in their diets but an additive effect was noted if the terrestrial species were grazers, that is, higher molar crowns for ground-level feeders and still higher for grass-eating ground-level feeders (Janis, 1988; Janis, 1998; Williams and Kay, 1999; Damuth and Janis, 2011; Damuth and Janis, 2014). In all of the above cases, the authors grant that the preponderance of wear could just as easily have originated from exogenous grit as from the physical properties of the foods. Even for arboreal species, dust accumulation in the trees from the ambient environment suggests that grit is a potential source of wear (Ungar et al., 1995).

A final consideration when studying rates of wear is that environmental conditions may adversely affect the development of the permanent dentition. While the potential mechanisms that could affect the mineralization process are numerous, a particularly well-studied condition in this regard is fluorosis. In a seminal review of the subject, Roholm (1937) described the thickening of joints and mottling of teeth in Icelandic sheep following volcanic eruptions. Roholm demonstrated that these symptoms are due to chronic fluorine intoxication, now known as "fluorosis". In describing the symptoms of fluorosis in the teeth of farm animals, Allcroft (1959) mentioned 
mottling, rapid and irregular wear, and staining. Similar symptoms were also found in wild populations of White-tailed deer (Odocoileus virginianus) (Karstad, 1967) and Black-tailed deer (Odocoileus hemionus columbianus) (Newman and $\mathrm{Yu}, 1976$ ). A recommended review of the multitude of studies of fluorosis in both domestic and wild populations of mammals is provided by Walton (1988).

In the present work we analyze tooth wear across the post-canine tooth row in several populations of the redmantled howling monkey (Alouatta palliata). This species has a wide geographical distribution in Central America encompassing a variety of forested habitats that vary in ecological stressors such as mean annual precipitation and seasonality of rainfall. In addition, the diet of the species is well documented from a variety of forested habitats: seasonal dry forests of Costa Rica and Nicaragua (Teaford and Glander, 1996; Travers, 1999; Williams-Guillén et al., 2013); and rainforests of Mexico and Panama (Milton, 1980; Estrada, 1984). In all areas, the largest proportion of the diet consists of leaves and flowers with fruit, especially figs, being a second important food source. On average, with seasonal variations, leaves and flowers account for $60 \%$ or more of the annual diet with fruit and other vegetal products accounting for most of the remainder. Importantly, many studies document that almost as much seasonal variation in diet may occur at one site as occurs among all sites taken together (Milton, 1980; Estrada, 1984; Hawes and Peres, 2013).

In light of the dietary similarity and universal arboreality of $A$. palliata living in a variety of habitats we propose the null hypothesis that the rate of tooth wear across the entire post-canine tooth row does not differ significantly as a function of environmental variables, i.e., that wear rates do not differ between populations in dry seasonal forests and populations in wetter, more equable forest settings. This hypothesis assumes that uniformity in diet and/or exogenous grit among the populations under study will be reflected in overall similarity in cumulative tooth wear (see Materials and Methods), and that variations in the environment (annual rainfall, seasonality) will have a negligible effect, whilst recognizing that microscopic wear surfaces may differ seasonally and in various microhabitats (Teaford and Glander, 1996). The null hypothesis is supported by King et al.'s (2012) who reported no differences in the rates of tooth wear (measured as exposed dentin) between recaptured sifakas (Propithecus verreauxi) and mouse lemurs (Microcebus rufus) living in humandisturbed versus undisturbed environments in the same national park. An alternative to the null hypothesis is that the rate of tooth wear will change with differences in environmental variables, relating to either a change in the physical properties of plant materials consumed, at least seasonally, or variation in the total yearly abundance of dust and grit in the environment.

Furthermore, several populations of howlers in our sample from Nicaragua were subject to significantly high amounts of volcanic ash fall for periods during their lives. Thus we have a natural experiment comparing individuals of the same species that lived in dry seasonal forests, some of which were subject to ash falls and some not. These populations are in fact the same as were observed by Smith et al. (1977) to have excessive wear, and this study will seek to quantify the observations of Smith et al. and compare them with wear in other populations of Central American howlers.

In this study, we use cross-sectional data on macroscopic tooth wear for individuals that range in dental

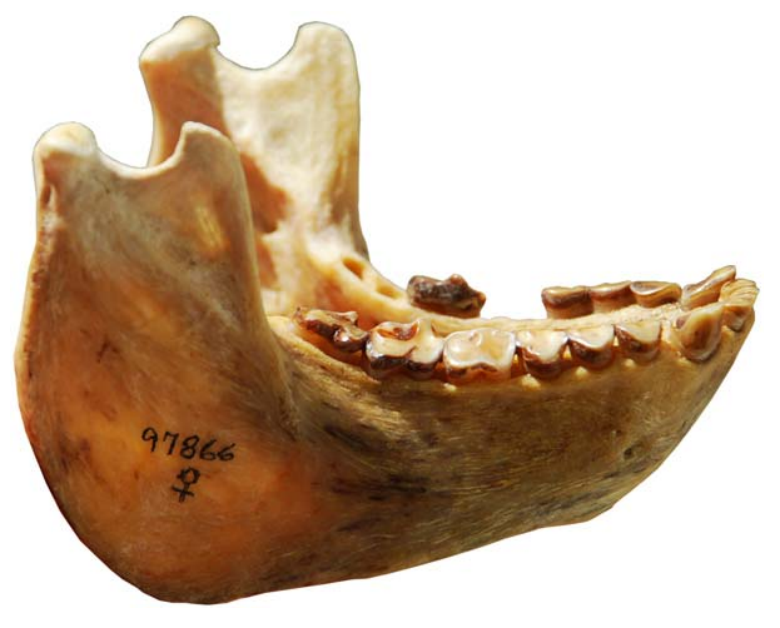

Fig. 1. KU 97866, an adult female Alouatta palliata from Moyogalpa, NW end of Isla de Omotepe, Nicaragua, near Volcán Concepción. Specimen collected by J. D. Smith 29 July, 1964. Shows extremely heavy wear on the premolars, canines and incisors. Volcanic eruptions occurred here December 1961, June 1962 and May 1963. [Color figure can be viewed in the online issue, which is available at wileyonlinelibrary.com.]

maturity and ageing (as indicated by tooth emergence and overall wear) from specimens preserved in museum collections and in some cases from plaster casts taken from individuals captured in the field. We test whether the overall pattern and rate of wear differs among sites clustered by environmental similarity and the presence or absence of volcanic dust.

\section{MATERIALS AND METHODS}

We examined cumulative tooth wear in 190 specimens of Alouatta palliata from Nicaragua, Costa Rica, and Panama (Table 1, Fig. 2). We define "cumulative tooth wear" as the total amount of wear on a given tooth from the time of eruption to the time of measurement (at death or at the time of capture). The collecting sites exhibit high isothermality (i.e., little seasonal variation in temperature compared with daily temperature range). They differ in mean annual precipitation (MAP) and seasonality of rainfall. The study sites in Panama are located in Bocas del Toro Province in the northeast part of the country. The area is covered by wet tropical forest vegetation with a MAP of $\sim 3,500 \mathrm{~mm} /$ year. Rain falls in abundance year round and the locality is not considered seasonal. In contrast, the localities of western Nicaragua and western Costa Rica feature tropical dry forests with distinct wet and dry seasons, with $1,200-1,300 \mathrm{~mm}$ of precipitation falling between May and November, whereas the other months receive a total of $200-300 \mathrm{~mm}$ on average.

An added factor considered in this study is the occurrence of volcanic ash. Many of the Nicaraguan specimens are located downwind of plinian volcanoes that were active during the lifetime of the individuals collected (Table 2). Records from volcanic eruptions over the past 75 years in Central America show that the prevailing winds consistently disperse ash and gases from the eruptions to the west (Kutterolf et al., 2007; Kutterolf et al., 2008); therefore, we identify populations as being affected by volcanic activity if the site from which they were collected was directly to west to southwest of the active volcano and the sites had experienced ash falls within 5 
TABLE 1. Localities sampled in the wear study

\begin{tabular}{|c|c|c|c|c|c|c|}
\hline Locality & Longitude and latitude & MAP & $\begin{array}{l}\text { Annual } \\
\text { temperature } \\
\text { range }\end{array}$ & $\begin{array}{l}\text { Temperature } \\
\text { seasonality }\end{array}$ & $\begin{array}{c}\text { Precipitation } \\
\text { seasonality }\end{array}$ & Isothermality \\
\hline Boca del Drago, Panama & $85^{\circ} 47^{\prime} 47^{\prime \prime W} 9^{\circ} 24^{\prime} 43^{\prime \prime N}$ & $2785 \mathrm{~mm} /$ year & 9 & 553 & 28 & 80 \\
\hline Almirante, Panama & $82^{\circ} 24^{\prime} 00^{\prime \prime W} 9^{\circ} 18^{\prime} 00^{\prime \prime N}$ & $2786 \mathrm{~mm} /$ year & 9.5 & 530 & 29 & 80 \\
\hline Isla Colon, Panama & $82^{\circ} 19^{\prime} 42^{\prime \prime W} 9^{\circ} 24^{\prime} 26^{\prime \prime} \mathrm{N}$ & $2785 \mathrm{~mm} /$ year & 9 & 553 & 28 & 80 \\
\hline $\begin{array}{l}.5 \mathrm{~km} \text { North of Merida, } \\
\text { Isla de Ometepe, Nicaragua }\end{array}$ & $85^{\circ} 32^{\prime} 06 ” \mathrm{~W} 11^{\circ} 27^{\prime} 16^{\prime \prime} \mathrm{N}$ & 2002 mm/year & 13.4 & 759 & 74 & 73 \\
\hline $\begin{array}{l}2 \mathrm{~km} \text { North of Merida, } \\
\text { Isla de Ometepe, Nicaragua }\end{array}$ & $85^{\circ} 33^{\prime} 40^{\prime \prime W} 11^{\circ} 28^{\prime} 09^{\prime \prime} \mathrm{N}$ & $1578 \mathrm{~mm} /$ year & 13.7 & 832 & 80 & 72 \\
\hline Diriamba, Nicaragua & $86^{\circ} 16^{\prime} 33^{\prime \prime} \mathrm{W} 11^{\circ} 52^{\prime} 43^{\prime \prime} \mathrm{N}$ & $1370 \mathrm{~mm} /$ year & 13.8 & 769 & 88 & 73 \\
\hline $\begin{array}{l}\text { Moyogalpa, Isla de Ometepe, } \\
\text { Nicaragua }\end{array}$ & $85^{\circ} 38^{\prime} 17^{\prime \prime W} 11^{\circ} 33^{\prime} 33^{\prime \prime N}$ & $1659 \mathrm{~mm} /$ year & 13.5 & 761 & 83 & 73 \\
\hline Nadaime, Nicaragua & $86^{\circ} 03^{\prime} 29 " \mathrm{~W} 11^{\circ} 45^{\prime} 22^{\prime \prime} \mathrm{N}$ & $1626 \mathrm{~mm} /$ year & 13.7 & 741 & 92 & 73 \\
\hline $\begin{array}{l}3 \mathrm{~km} \text { South \& } 5 \mathrm{~km} \\
\text { West of Nadaime, } \\
\text { Nicaragua }\end{array}$ & $86^{\circ} 06^{\prime} 03^{\prime \prime} \mathrm{W} 11^{\circ} 43^{\prime} 46^{\prime \prime} \mathrm{N}$ & 1609 mm/year & 13.8 & 760 & 93 & 73 \\
\hline $\begin{array}{l}13 \mathrm{~km} \text { South \& } 5 \mathrm{~km} \\
\text { West of Nadaime, } \\
\text { Nicaragua }\end{array}$ & $86^{\circ} 06^{\prime} 00^{\prime \prime W} 11^{\circ} 38^{\prime} 23^{\prime \prime} \mathrm{N}$ & $1713 \mathrm{~mm} /$ year & 13.9 & 756 & 92 & 73 \\
\hline Mecatepe, Nicaragua & $85^{\circ} 56^{\prime} 48^{\prime \prime W} 11^{\circ} 46^{\prime} 27^{\prime \prime} \mathrm{N}$ & 1509 mm/year & 13.7 & 743 & 92 & 73 \\
\hline Hacienda Amayo, Nicaragua & $85^{\circ} 42^{\prime} 20^{\prime \prime W} 11^{\circ} 19^{\prime} 03^{\prime \prime N}$ & 1646 mm/year & 13.9 & 792 & 80 & 73 \\
\hline $\begin{array}{l}13 \mathrm{~km} \text { South \& } 11 \mathrm{~km} \text { East } \\
\text { of Hacienda Amayo }\end{array}$ & $85^{\circ} 37^{\prime} 29^{\prime \prime W} 11^{\circ} 13^{\prime} 09^{\prime \prime} \mathrm{N}$ & $2102 \mathrm{~mm} /$ year & 14.1 & 830 & 67 & 72 \\
\hline NW of Sapoa, Nicaragua & $85^{\circ} 39^{\prime} 46^{\prime \prime W} 11^{\circ} 16^{\prime} 27^{\prime \prime} \mathrm{N}$ & $1892 \mathrm{~mm} /$ year & 14 & 823 & 72 & 72 \\
\hline $\begin{array}{l}\text { Centro Ecologico La Pacifica, } \\
\text { Costa Rica }\end{array}$ & $85^{\circ} 07^{\prime} 41^{\prime \prime} \mathrm{W} 10^{\circ} 27^{\prime} 14^{\prime \prime} \mathrm{N}$ & 1615 mm/year & 13.6 & 704 & 86 & 76 \\
\hline $\begin{array}{l}\text { Finca Santa Cecilia, } \\
\text { Nicaragua }\end{array}$ & $86^{\circ} 01^{\prime} 01^{\prime \prime} \mathrm{W} 11^{\circ} 51^{\prime} 00^{\prime \prime} \mathrm{N}$ & 1896 mm/year & 13.7 & 771 & 87 & 72 \\
\hline
\end{tabular}

Climate data from WorldClim database (http://www.worldclim.org/)

years of the collection, thereby assuring that most of the population were adults during a time of volcanic activity and presumably had some exposure to the volcanic ash accumulated on vegetation. In summary, the sample consists of specimens collected from wet tropical forests with no ash falls and dry tropical forests with and without ash falls during the lifetimes of the individuals.

Data were gathered from osteological specimens, highresolution epoxy casts, and plaster casts drawn from dental molds of living animals in the field (Supporting Information Table 1). Specimens examined from the Museum of Natural History of the University of Kansas (KU) were collected between 1962 and 1968 downwind of the active stratovolcanoes Concepción and Masaya ${ }^{1}$. When known, the age and sex of the specimens were recorded. Only individuals that had all premolars and molars fully erupted and in occlusion and that exhibit no post mortem damage were evaluated. We did not detect differences between measurements of different materials (bone, epoxy, or plaster), but the specimen material is recorded for all specimens in the Supporting Information Table 1.

\section{Molar measurements}

Line drawings were made of occlusal views of the lower molar rows using a Wild Heerbrugg M5 1220

\footnotetext{
${ }^{1}$ Field notes made by mammalogists J. D. Smith and J. K. Jones housed in the University of Kansas Mammals collection indicate that the Alouatta specimens were collected at the time of volcanic dust accumulation: Jones: March 8, 1968: "Dust covered most of the vegetation and may have been a partial detriment to the mice.” Jones: February 29, 1968: "El Paraíso, (1 km n Cosigüina, 20 miles, Chinandega, Nicaragua.... from the turnoff into Cosigüina $\pm 2 \mathrm{~km}$.) is nothing but deep ruts and pumice dust, which is like talcum powder." ... March 3, 1968: "Arrived at Cosigüina at 5:00 PM after the truck drowned out in the dust twice.”
}

microscope fitted with a measuring reticle and camera lucida. The camera lucida works by superimposing the subject being viewed upon a drawing surface, allowing both the subject and drawing surface to be seen simultaneously. The outline profiles of each tooth and the perimeter of its exposed dentin were traced and size corrected from the reticle measurement of tooth length (Fig. 3). One concern when making sketches is the torsion of the molar teeth relative to one another, such that the occlusal surfaces are arranged in a helicoidal wear plane. Since we did not control for this, it is a potential source of error when taking measurements. However, this error should be small and relatively equal between the three molars and is unlikely to affect our results significantly. Sketches were digitally scanned using an Epson Perfection V500 Photo Scanner and uploaded to Image-J (version 1.46r). Using Image-J's measuring tools, the total projected crown area and the total projected area of exposed dentin were measured and recorded for each molar.

Tooth wear on each molar is expressed as the ratio of exposed dentin area to total tooth area in the occlusal plane. Assuming a dental eruption sequence of $\mathrm{M}_{1}-\mathrm{M}_{2^{-}}$ $\mathrm{M}_{3}$ (Schultz, 1935) and similar timing of tooth eruption in all populations, wear rate is expressed as the ratio of $M_{1}$ wear to $M_{2}$ wear (and $M_{2}$ wear to $M_{3}$ wear). This method is similar to previous studies of wear gradients in humans (Molnar, 1971; Smith, 1972; Lunt, 1978). All measurements are presented in Supporting Information Table 1.

\section{Premolar measurements}

Premolar wear classes were established on criteria of wear (Table 3, Fig. 4). This "meristic" scale was chosen over a continuous one primarily as a heuristic. It is true 

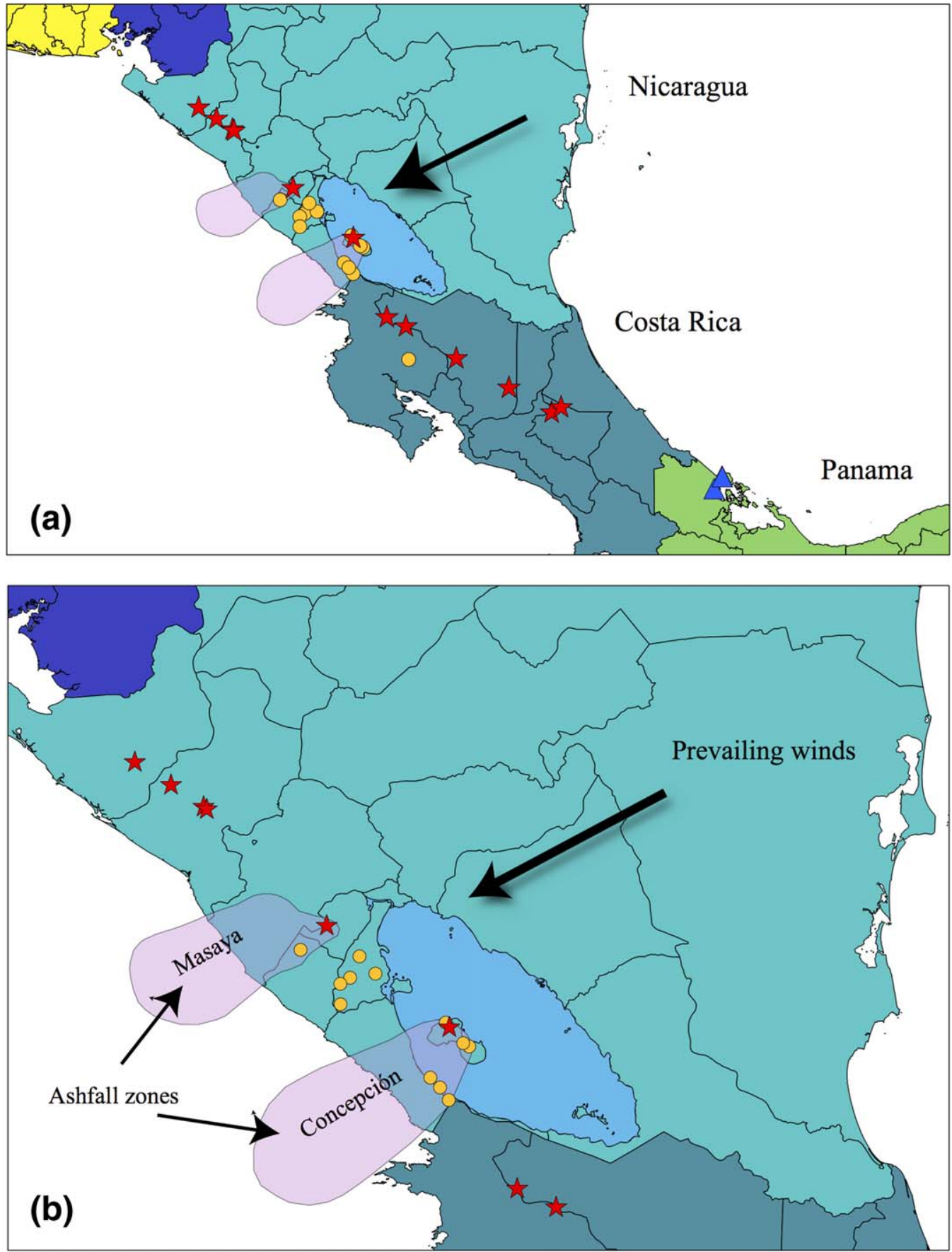

Fig. 2. A: Map of Central America indicating the position of the collection sites for Alouatta palliata. Active volcanoes are indicated by the red stars. Dry forest sites are indicated by yellow circles. Rainforest sites are indicated by blue triangles. Distribution of ash falls that impacted the specimens under study is illustrated by the pink shading. Direction of prevailing winds is indicated by the black arrow. B: Close-up view of Nicaraguan sites and ash falls from Masaya and Concepción volcanoes. Data from http:// www.volcano.si.edu/. [Color figure can be viewed in the online issue, which is available at wileyonlinelibrary.com.]

however, that the variable patterns of wear in the premolars, compared to the consistent patterns seen in the molars, makes the drawing of exposed dentin in a single plane extremely difficult. Thus to eliminate this problem and potential source of error, we chose to characterize premolar wear categorically. To compare premolar wear to molar wear on each specimen, molar wear classes were established based on quartiles from the distribu- tion of $\mathrm{M}_{1}$ wear across all specimens examined. For example, all specimens with $\mathbf{M}_{1}$ wear at or below the $25 \%$ quartile (0.039 exposed dentin area relative to total area in our sample) were scored at wear category 1 , specimens that fell between the $25 \%$ quartile and the median (0.039-.0113) were scored at wear category 2, and so forth. All premolar measurements are in Supporting Information Table 1. 
TABLE 2. Summary of active volcanic eruptive episodes at times when specimens would have been alive

\begin{tabular}{|c|c|c|c|c|}
\hline Volcano & Dates of active eruptions & Sites affected & $\begin{array}{l}\text { Years of specimen } \\
\text { collections }\end{array}$ & $\begin{array}{c}\text { Number of specimens } \\
\text { examined }\end{array}$ \\
\hline Volcán Concepción & $\begin{array}{l}\text { December 1961; June } \\
\text { 1962; May 1963 }\end{array}$ & $\begin{array}{l}\text { Isla de Ometepe; } \\
\text { Hacienda Amayo; } \\
\text { Moyogalpa; NW of Sapoa }\end{array}$ & 1962 - 1968 (Smith, 1977) & 45 \\
\hline Volcán Masaya & $\begin{array}{l}\text { Continuous eruptions from } \\
\text { October 1965-April } 1985\end{array}$ & Finca Amayo & $1962-1968$ (Smith, 1977) & 11 \\
\hline
\end{tabular}

Notes: Dates of eruption from database at Smithsonian institution. Specimens collected by Smith Genoways and Jones, stored at University of Kansas Natural History Museum; see Smith et al., 1997\}. Nearby localities from the list in Table 1 have been consolidated for space.

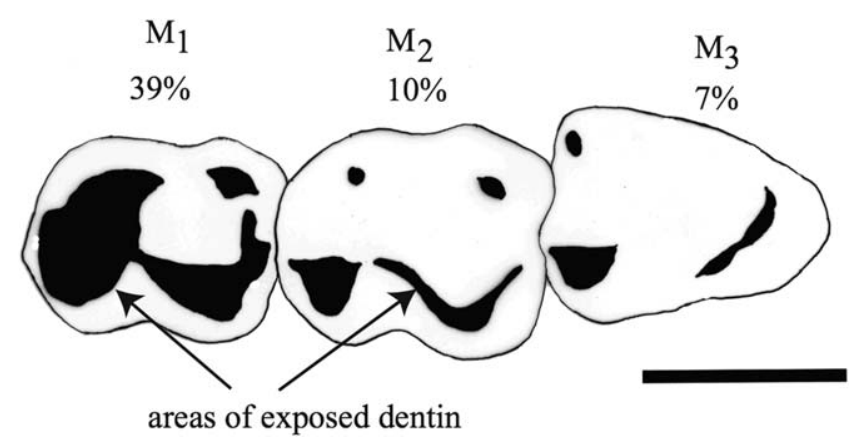

Fig. 3. Scale outline drawings of left $\mathrm{M}_{1-3}$ of Alouatta palliata (KU 97861) from $5 \mathrm{~km}$ east of Moyogalpa near Vulcan Concepción, collected in 1964. Black areas indicate places on the crown where the enamel is perforated exposing the underlying dentin. The amount of exposed dentin is given as a percentage of the crown area of each tooth. Scale bar equals $5 \mathrm{~mm}$.

\section{Statistical methods}

All statistical analyses were performed in JMP® Pro 10 or R Studio ${ }^{\circledR}$. Linear regressions were used to evaluate the relationship between molars. A log-linear analysis is a technique that seeks to determine what model components (main effects and/or interactions) best account for the data from three or more categorical variables, and thus a Model I log-linear test of independence was used to test for three-factor, two-factor, and main effect associations of the factors: habitat type, $M_{1}$ wear, and $\mathrm{P}_{2-4}$ wear.

TABLE 3. Definition of wear stages for premolars (as illustrated in Fig. 4)

Premolar

wear Score

Description

Stage 1 Tooth wear is minimal, exposure of dentin limited to cusp tips and producing at most only a tiny enamel puncture at the very tip of the largest cusp.

Stage 2 Tooth shows noticeable dentin exposure, but $<50 \%$ of crown. Cusp tip is blunted or flat due to wear, but cusp itself is still prominent. All crests are still present.

Stage 3 Tooth shows considerable wear. Dentin exposure is $>50 \%$ relative to enamel.

Stage 4 Tooth is heavily worn or even lost in life lost due to wear. Little enamel remains on the occlusal surface.

\section{RESULTS Climate groupings}

A Principal Components Analysis of the collecting localities was undertaken using the five climate variables. The first two Principal Components explain 98.3\% of the variance of the system (Fig. 5). High values on PC1, encompassing, $92 \%$ of the variance, separate localities with high precipitation and isothermality from localities with marked precipitation and temperature seasonality, and low isothermality. PC2 (6.3\%) achieves little separation among the localities. Based on these findings we have divided the localities into two "climates"-the first being isothermal and high precipitation with a small annual temperature range and without strong rainfall seasonality, and the second with lower and more seasonal rainfall and a strong seasonality in temperature. The first climate is associated with rainforests and the second with seasonally dry forests. Figure $2 \mathrm{~A}$ and B illustrate the geographic distribution of these two climatic groups and indicates which collecting localities experienced periodic ash falls during the lives of the collected specimens.

Regardless of which environment is considered, and in keeping with the assumed tooth eruption sequence $\mathbf{M}_{1}$ $\mathrm{M}_{2}-\mathrm{M}_{3}$, wear on the cheek teeth proceeds in a uniform manner in all samples, as expressed by least-squares regression between wear on $M_{1}$ versus that on $M_{2}$ (and $M_{2}$ versus $M_{3}$ ) (Table 4 ). Testing whether wear rates are similar for each molar is complicated by the sample having an overrepresentation of younger individuals with very little wear. To control for unequal numbers of individuals at different wear stages, we binned the wear data for each molar into quantiles. The median values of $\mathrm{M}_{1}$ and $\mathrm{M}_{2}$ wear were determined for each wear category. Plotting the logs of the median values for $M_{1}$ (ordinate) and $M_{2}$ (abscissa) the slope is 1.003 (isometry) with an intercept of -0.91 (Fig. 6). We interpret this to mean that $M_{1}$ and $M_{2}$ wear at equal rates and that the wear difference between the two molars is a simple function of the uniform timing of the eruption of $\mathrm{M}_{1}$ before that of $\mathrm{M}_{2}$.

Figure 7 presents bivariate plots of the three pairs of molars, with data grouped by habitat type. If molar wear proceeded more rapidly in some environments, we would expect a steeper slope when comparing $\mathrm{M}_{1}$ wear with $\mathrm{M}_{2}$ wear (or $\mathrm{M}_{2}$ with $\mathrm{M}_{3}$ ). However, we find no significant differences among the slopes (or intercepts) of wear in either real space or log space regardless of climate or the presence of ash (Table 4).

Another way to consider the molar wear data is to analyze $\mathbf{M}_{1}$ wear in our sample of individuals with similar wear on $\mathrm{M}_{3}$. If wear rates differ, we would expect to find more wear on $\mathrm{M}_{1} \mathrm{~s}$ of individuals depending on climate. First, we selected specimens for which the $\mathrm{M}_{3}$ wear is low (Group 1: mean ratio of wear of dentine to total area on 


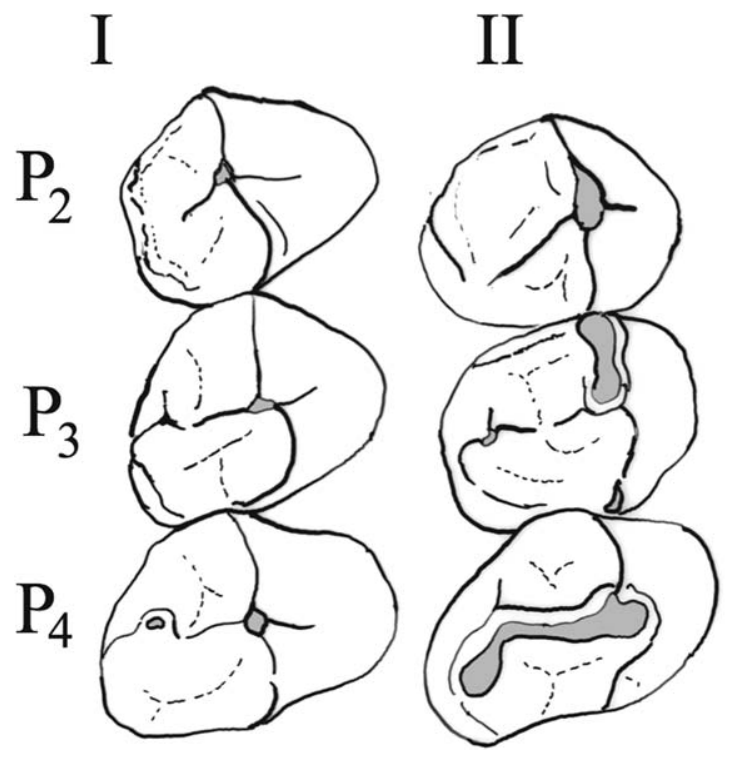

III

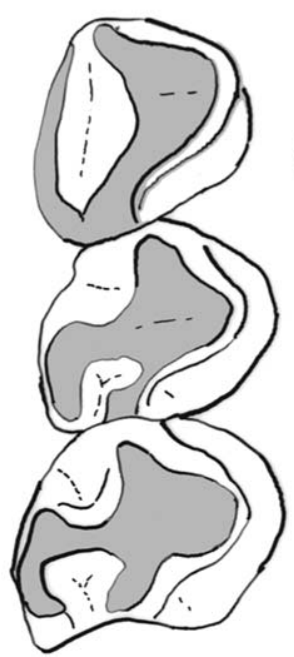

IV

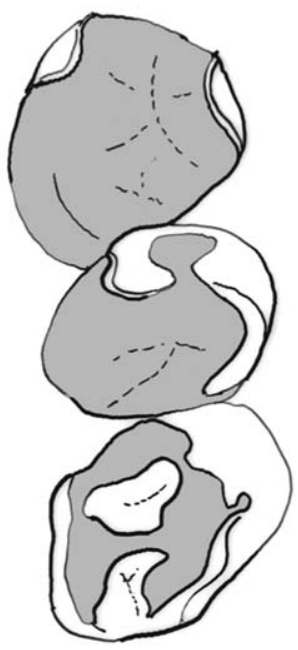

Fig. 4. Illustration of premolar wear stages.

$\mathrm{M}_{3}$ is 0.0137 (ash habitat), 0.0132 (dry habitat, no ash), 0.0137 (wet habitat, no ash), and then calculate the ratio of $\mathrm{M}_{1}$ wear (numerator) to $\mathrm{M}_{3}$ wear (denominator). Assuming similar tooth eruption schedules, the $M_{1}: M_{3}$ ratio should be higher if $\mathrm{M}_{1}$ has worn more rapidly in life, and lower if wear was less severe (Kay et al., 2002). We find the mean ratio of rain forest individuals to be lowest $(3.77 \pm 0.42)$, and higher in dry forests $(5.47 \pm 0.42)$ and dry forest with ash $(5.87 \pm 0.96)$. Thus we find an overall trend, but as will be clear from the standard errors, none of these differences approaches significance (rain forest versus dry forests with or without ash yield $P$-values of 0.14 and 0.16 , respectively).

Considering that the ratio data may not be not normally distributed, a nonparametric comparison for each pair using the Wilcoxon method was also employed. Here again, the two dry forest samples do not differ significantly $(P=0.71)$. The rain forest sample has somewhat less wear than that of the dry forest with and without ash ( $P$-values of 0.24 and 0.08 , respectively). A potential problem with our sample comparisons is the imbalance in sample size: there are 19 rain forest specimens, 115 dry-forest specimens and 56 specimens from dry forests with ash. A bootstrapping analysis using an $N=19$ resampling strategy on the dry-forest specimens showed that the median wear value for $M_{1}(0.085)$ of the wet-forest population was within the inter-quartile range of the random samples from the dry-forest population $(0.065-0.493)$.

\section{INTER-SITE VARIATION IN PREMOLAR WEAR}

In contrast to the lack of significance among molar wear rates among the three habitat variables (wet, dry, dry with ash) we do find premolar wear differences in relation to habitat type and presence of ash dust. Visual inspection of Figure 8A-C shows that, given a comparable amount of molar wear between the three habitats, premolar wear in specimens from the dry forests with ash is greater than that from specimens from rain forests or dry forests without ash. In Figure 8A-C each cell contains the percentage of the population that fits into the corresponding wear categories of molar and premolar wear. For example, the cell corresponding to "One-One" represents the percentage of specimens in the sample in which both the $\mathrm{M}_{1}$ and $\mathrm{P}_{2}$ were scored in the lowest wear category.

In general, the specimens show a similar pattern of wear. The largest percentages of specimens are concentrated in the diagonal elements of the matrix indicating that the premolars and molars are at similar stages of wear. The specimens from the ash-free environments (regardless of climate) have large percentages of specimens with premolar wear scores that are lower than their corresponding molar wear scores $(36.9 \%$ for wet and $28.7 \%$ for dry). In contrast, a much higher percentage of specimens from ash environments have premolar wear scores that exceed their molar wear scores than do ash-free wet and dry habitats $(40.5 \%$ for ash environments compared with $15.8 \%$ and $7.4 \%$, for wet and dry ash-free environments). Indeed, only one specimen from the ash-fall group has a premolar wear score lower than the molar wear score. This is consistent with the observations made by Smith et al. (1977), who noted particularly heavy wear in the anterior dentition relative to the posterior.

The above observations are supported by statistical analysis. The log-linear analysis performed on a $3 \times 4 \times$ 4 table showed that: (1) the three factors (habitat type, molar wear, premolar wear) were independent from one another; and (2) the frequency distributions of molar and premolar wear for wet habitats and dry habitats with ash were significantly different from the null, i.e., a one-to-one linear distribution of premolar wear to molar wear ( $P<0.001$ for both habitat types).

\section{DISCUSSION}

In our samples the rate of $\mathrm{M}_{1}$ wear compared to the rate of $\mathrm{M}_{2}$ wear does not differ significantly between populations of $A$. palliata living in humid environments and those living in dryer, more seasonal environments. This finding is consistent with, and extends that of a previous study of A. palliata by Dennis et al. (2004). 
A

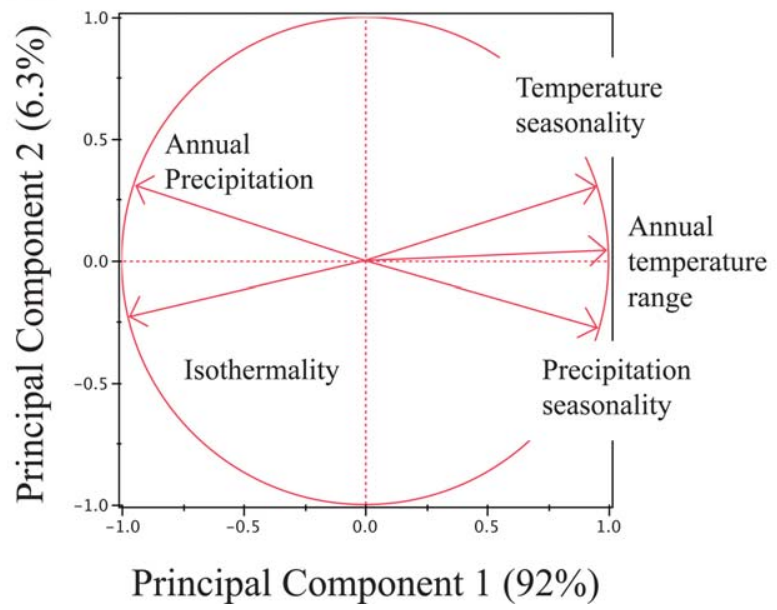

$\mathrm{B}$

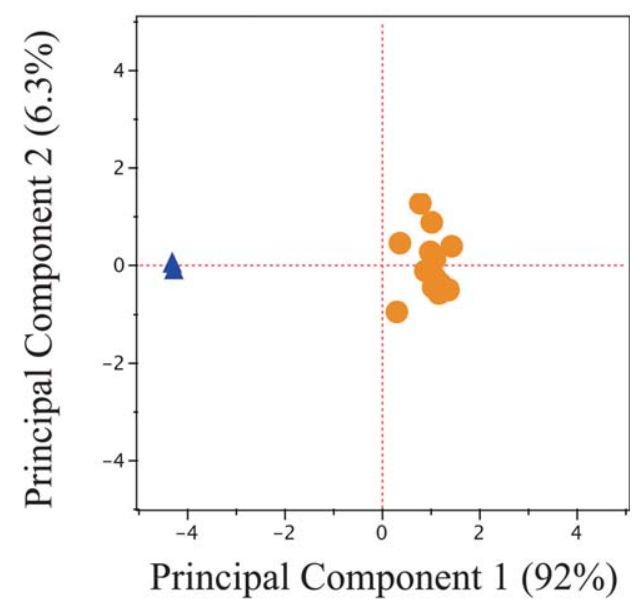

Fig. 5. Principal components analysis of five environmental variables at the study sites. A: Factor loadings of the five variables on each of the first two principal components: isothermality $(-0.45,-0.40)$; annual precipitation $(-0.44,0.55)$; annual temperature range $(0.46,0.07)$; precipitation seasonality $(0.44,-0.49)$; and temperature seasonality $(0.44,-0.54)$. B: Plot of first two principal components for the localities under study. Seasonal and dry localities (orange filled circles) cluster to the right; equable and wet localities (blue filled triangles) cluster to the left. [Color figure can be viewed in the online issue, which is available at wileyonlinelibrary.com.]

Dennis et al. examined tooth wear longitudinally in individuals living in two populations from the same site in Costa Rica (one of our groups consists primarily of individuals from this site). One population inhabits riverine gallery forest whereas the other, consisting of two groups, is found in drier forest patches without access to the river. No significant differences were reported for a suite of functionally related measures of $\mathrm{M}_{2}$ tooth wear between riverine and non-riverine habitats. Dennis et al. hesitated to conclude that their finding is robust on account of the small samples involved (6 non-riverine versus 8 riverine individuals at three ages) but our cross-sectional data appears to support their tentative conclusions. An added caveat is that the habitats studied by Dennis et al. are much more narrowly defined that those we identified. Nevertheless our analyses point in precisely the same direction: that environmental differences experienced within this arboreal leaf-eating species has at best a limited cumulative effect on molar wear. That the habitats that we used to distinguish samples included much broader differences in climate
( $\sim 2,000 \mathrm{~mm}$ difference in MAP) serves to reinforce the conclusions of Dennis et al. This is also consistent with the findings of King et al. (2012) who reported no differences in wear rates between habitats that were disturbed or undisturbed by humans.

There is an overall trend for there to be proportionally more wear on $M_{1}$ s matched for $M_{3}$ wear (mean wear of ashfall individuals $>$ dry forest individuals $>$ wet forest individuals) but the difference does not rise to the level of significance. The ashfall specimens do have exceptionally heavy wear on the premolars, and while incisors were not include the in our study, our impression is that the incisors also are heavily worn. In the absence of behavioral data, we can only speculate as to the likely cause. The most likely explanation is the differential use of the anterior dentition, including the premolars, to strip away the foliage and free it from grit during ingestion with the anterior dentition, including the premolars, thereby exposing the anterior teeth to heavier loads of grit adhered to the leaves than is the case for the molars. Other alternatives cannot be ruled out. Perhaps the individuals

TABLE 4. Least-squares regression comparing wear on one tooth versus wear on another, each expressed as a percentage

\begin{tabular}{lccc}
\hline Teeth compared & $\begin{array}{c}\text { Number of } \\
\text { specimens }\end{array}$ & Intercept & Slope \\
\hline $\mathrm{M}_{1}$ vs. $\mathrm{M}_{2}$ & & & \\
Wet forest & 19 & -0.014 & $0.679 \pm 0.056$ \\
Dry forest without ash & 115 & -0.018 & $0.540 \pm 0.023$ \\
Dry forest with ash & 56 & -0.027 & $0.628 \pm 0.068$ \\
$\mathrm{M}_{1}$ vs. $\mathrm{M}_{3}$ & 19 & -0.002 & $0.358 \pm 0.033$ \\
Wet forest $_{\text {Dry forest without ash }}$ & 115 & -0.008 & $0.333 \pm 0.017$ \\
Dry forest with ash & 56 & -0.027 & $0.427 \pm 0.049$ \\
$\mathrm{M}_{2}$ vs. $\mathrm{M}_{3}$ & 19 & 0.005 & $0.530 \pm 0.019$ \\
Wet forest & 115 & 0.007 & $0.577 \pm 0.025$ \\
Dry forest without ash & 56 & -0.008 & $0.678 \pm 0.023$ \\
Dry forest with ash & & & 0.8737 \\
\hline
\end{tabular}

The first variable is the independent variable and the second is the dependent variable. Slopes are presented along with standard errors. 


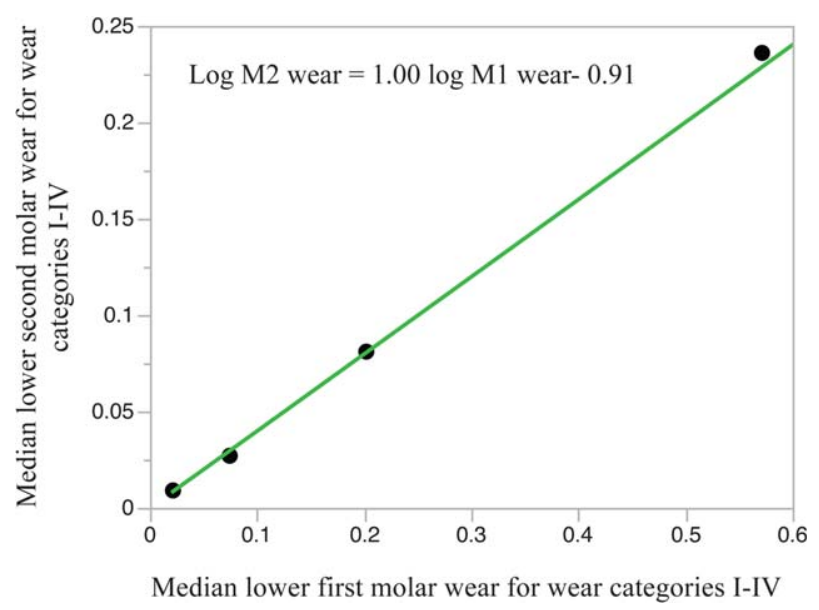

Fig. 6. Median values of wear Classes I-IV (molars) versus I-IV (premolars). [Color figure can be viewed in the online issue, which is available at wileyonlinelibrary.com.]

identified in the ashfall areas had some regionally distinctive ingestive behavior compared with the other populations.

A correlative, and testable, possibility involves the heightened presence of fluoride during the development of the teeth, which may have the effect of reducing the hardness of enamel as it is being formed. High fluoride levels have been linked through enamel maturation with increased dental abrasion and dental disease (Riede and Wheeler, 2009).Working with a population of European roe deer (Cervus capreolus) in a polluted environment characterized by high levels of fluoride, Kierdorf et al. (1993) demonstrated that crown development of the first two permanent molars occurs to a large extent prenatally, before the individual has consumed the fluoride in the environment. However, the last permanent molar and the permanent premolars are developing after the animals are born and begin to consume food with high levels of fluoride. The effects of fluorosis could clearly be seen in the dental fluorosis of tooth crowns of C. capreolus, contributing to a faster rate of wear in this part of the dentition. Flueck and Smith-Flueck (2013) found a naturalistic example parallel to that we observed in Alouatta. in their study of Patagonian deer following a volcanic eruption. They report that among subadults, tephra caused pathologic development of newly emerging teeth including extremely rapid wear of entire crowns down to underlying pulp cavities (dental fluorosis).

Flourosis might be expected in the volcanically influenced Alouatta populations. In Alouatta, the first and second molars are the first to erupt, preceding the eruption of the premolars. While we do not have ages of our Alouatta specimens at the time of the volcanic eruptions, it seems possible that the specimens showing particularly heavy wear in the premolar could have been individuals whose first and second molars had fully mineralized and erupted but in which the premolars and canines were still developing their enamel during and postdating the volcanic eruptions. The accompanying surge of environment fluoride in the ingesta could have weakened the enamel of yet-to-be fully developed premolars.

On the available evidence we prefer the dietary grit explanation. This conclusion is supported by the following observations by Smith et al. (1977):

"While collecting specimens on Isla de Ometepe (a volcanic island), we noted that the foliage of trees in areas inhabited by howler monkeys frequently was covered with volcanic dust. No doubt such abrasives contribute materially to accelerated attrition in some environments because 7 individuals (all females) from the island exhibited heavy to extreme dental wear."

Further support would be gained for the grit-based hypothesis is found in another species living in the ashfall areas. Romero and Timm (2013) report excessive dental wear in the arboreal rodent Nyctomys sumichrasti from
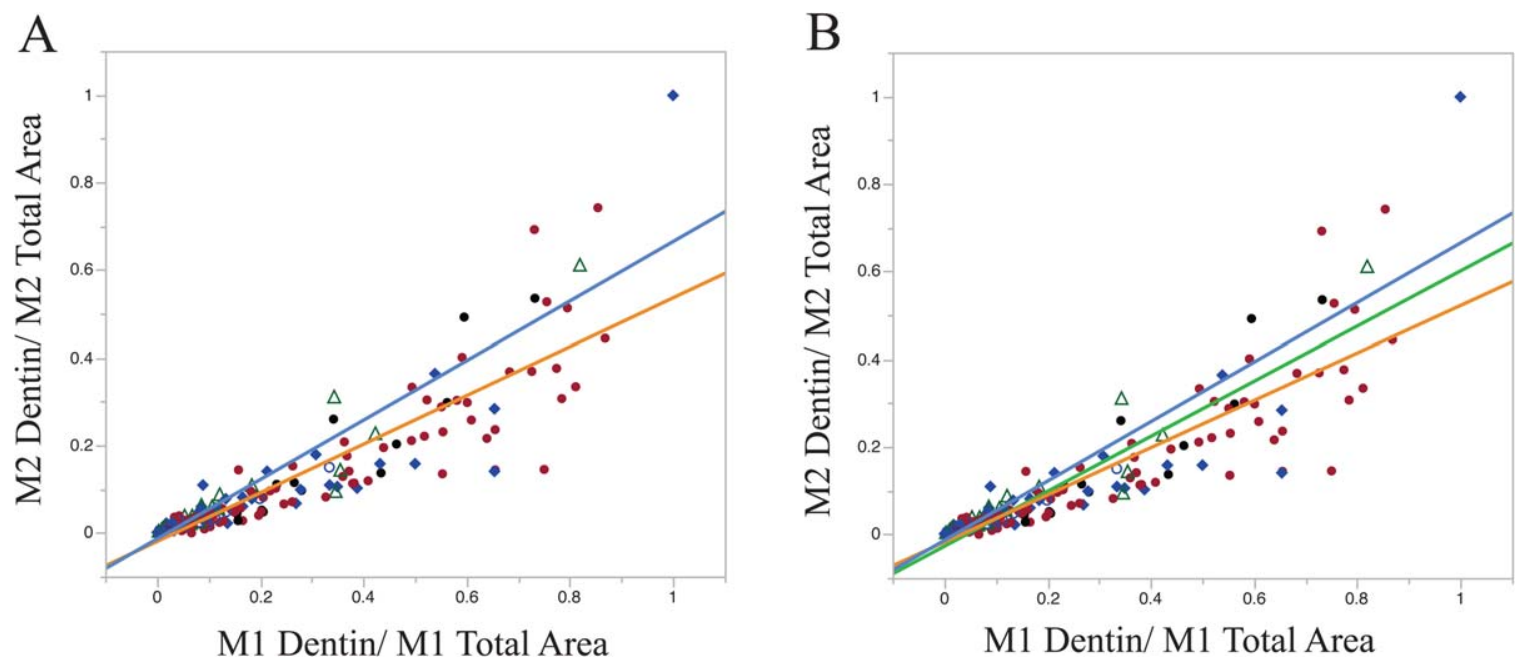

Fig. 7. Bivariate fits and linear regressions of $\mathrm{M}_{1}$ vs. $\mathrm{M}_{2}$. Regressions are grouped by habitat type. A: Specimens separated only by MAP. Dry forests $(\approx 1,500 \mathrm{~mm} /$ year $)$ are represented by an orange line. Rain forests $(>2,500 \mathrm{~mm} /$ year $)$ are represented by a blue line. B: Dry forest specimens further separated into those that experienced ash fall (green) and those that did not (orange). Similar results were obtained for $M_{1}$ vs. $M_{3}$ and $M_{2}$ vs. $M_{3}$ (see Table 4). [Color figure can be viewed in the online issue, which is available at wileyonlinelibrary.com.] 
A.

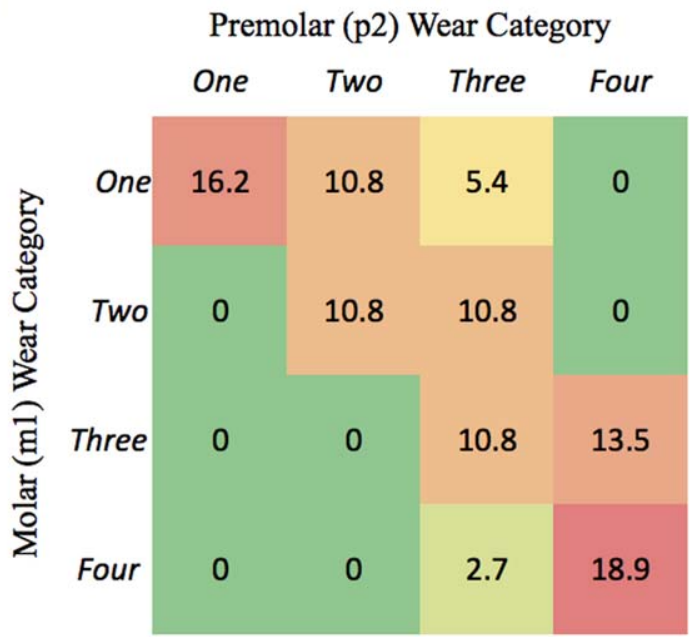

C.

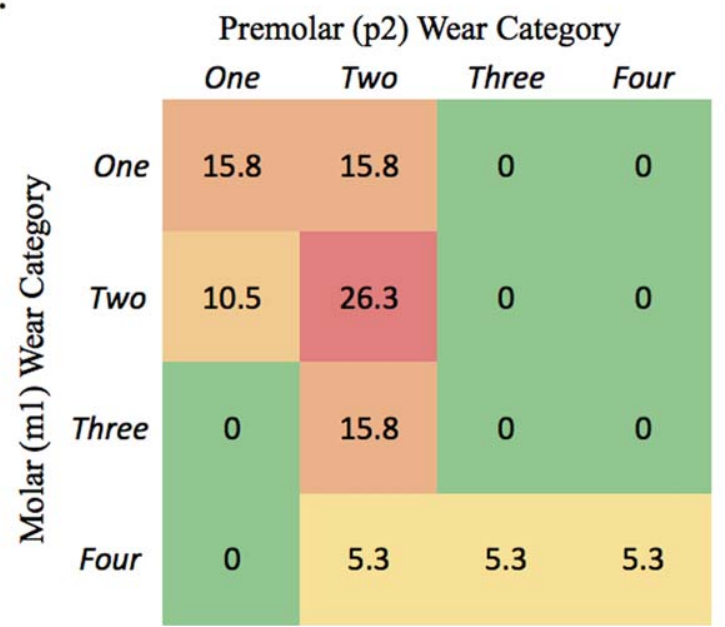

B.

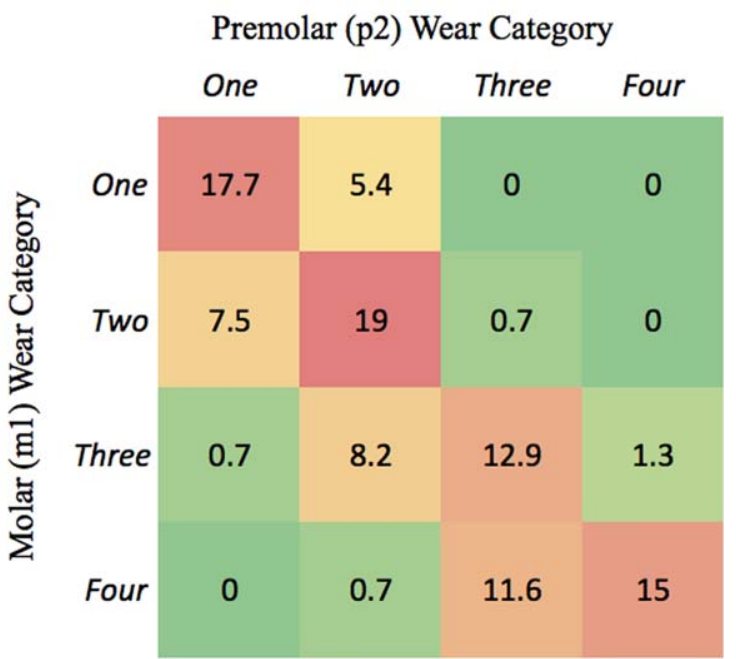

Fig. 8. $P_{2}$ wear vs. $M_{1}$ wear (expressed as $\%$ of population). A: Dry forests that experienced ash fall. B: Dry forests with no recorded ash fall. C: Wet forests. [Color figure can be viewed in the online issue, which is available at wileyonlinelibrary.com.]

the Nicaraguan localities as our A. palliata specimens. When trying to use the tooth wear based protocol developed by Genoways and Jones (1972) for ageing N. sumichrasti individuals from Nicaragua, Romero and Timm found that specimens from the Caribbean were grossly underestimated, suggesting that the difference between the two environments was heavily influencing tooth wear.

Our findings have broad implications concerning the long-term health and demographic profile of the animals subjected to plinian eruptive events, including severe craniodental pathologies described by Smith et al. (1977) such as plagiocephaly, dental caries, severe attrition, and mechanical loss of teeth, all of which were attributed by the authors at least in part by the presence of ash in the environments of collected specimens.

Our findings contribute important information in the ongoing debate as to the relative importance of endogenous versus exogenous material in shaping longer-term evolutionary trends in mammalian dental structure. Was dental evolution shaped primarily by the physical properties of the food consumed (e.g., hardness, toughness), especially including ingestion and mastication of abrasive endogenous plant silica? And what is the role of the intermittent injections of exogenous particles and high levels of fluoride from volcanic eruptions or from other dust or soil particles? Volcanic dust in some circumstances produces significant changes in the rate of tooth wear and must be considered as an important selective force shaping tooth functional longevity.

Heavy attrition leading to dental senescence and tooth loss might be an effect of intermittent influx of exogenous grit, volcanic ash as in this case, but be undetectable in microwear studies. If the animal survives the ashfall insult, it would return to feeding on plants that produce a characteristic microwear signal, one that can become evident within just a few days of the removal of the grit source. Viewed in this way, microscopic wear typically informs us about the immediate effects of commonly ingested food items whereas macrowear results from of the totality of wear produced by short-term ingestion of exogenous grit, weakening of developing tooth enamel, plus longer term wear from food physical properties. A disjunct would then be found between what the animal eats every day (the microwear signal) and the rapid attrition caused by short intermittent events expressed only in macrowear. The effects of the 
"normal" and the "unusual" each should contribute to evolutionary trends in the masticatory apparatus.

\section{CONCLUSIONS}

Our findings from this study can be summed in three points:

1. Comparison of the relative rate of wear on $\mathbf{M}_{1}$ is similar to that on $\mathrm{M}_{2}$, with eruption time likely the primary explanation for differences in wear between the teeth. The same is true for $M_{3}$ relative to $M_{1}$ and $\mathrm{M}_{2}$.

2. Although trends were noted, no significant differences are found between molar wear gradients of Alouatta palliata populations living in rain forests compared with those living in dry forests. Nor are there statistically significant molar wear differences between populations that lived in similar dry-forest environments with and without volcanic dust events.

3. Individuals that lived through volcanic ash events have significantly more premolar wear compared with those that did not, irrespective of whether they inhabited regions with wet equable or dry seasonal environments. The possibility is raised that fluorosis, by weakening premolar enamel is a contributing factor.

\section{ACKNOWLEDGEMENTS}

We would like to thank the following individuals for their contributions to this work: Dr. Robert Timm for allowing access to Nicaraguan specimens at the University of Kansas and for valuable discussions about tooth wear in other species from the ash sites; Dr. Chris Wall for help with statistical methods; and for two anonymous reviewers and especially the associate editor for their comments and suggestions.

\section{LITERATURE CITED}

Ainamo J. 1977. Prenatal occlusal wear in guinea pig molars. Euro J Oral Sciences 79:69-71.

Allcroft R. 1959. Fluorosis in farm animals. The effects of pollution on living material Symposia of the Institute of Biology 8 .

Barrett MJ. 1958. Dental Observations on Australian Aborigines. Aust Dent J 3:39-52.

Broca P. 1879. Instructions relatives à l'étude anthropologique du système dentaire. Bulletins De La Société D'anthropologie De Paris III $^{\circ}$ Série. Tome 2:128-163.

Campbell TD. 1939. Food, Food Values and Food Habits of the Australian Aborigines in Relation to Their Dental Conditions. Australian J Dentistry 43:1-15, 45-55, 73-87, 141-156, 177-198.

Cuozzo FP, Sauther ML. 2006. Severe wear and tooth loss in wild ring-tailed lemurs (Lemur catta): A function of feeding ecology, dental structure, and individual life history. J Hum E 51:490-505.

Dahlberg AA. 1963. Dental evolution and culture. Hum Biol 35: $237-249$.

Damuth J, Janis CM. 2011. On the relationship between hypsodonty and feeding ecology in ungulate mammals, and its utility in palaeoecology. Biol Rev 86:733-758.

Damuth J, Janis CM. 2014. A comparison of observed molar wear rates in extant herbivorous mammals. Ann Zool Fenn 51(1-2):188-200.

Davies TGH, Pederson PO. 1955. The degree of attritrion of the deciduous teeth and first permanent molars of primitive and urbanised Greenland natives. Br Dentistry J 99:35-43.

Dennis JC, Smith TD, Bhatnagar KP, Bonar CJ, Burrows AM, Morrison EE. 2004. Expression of neuron-specific markers by the vomeronasal neuroepithelium in six primate species. Anatomical Record 281A:
Dunn RE, Kohn MJ, Madden RH, Strömberg CE, Carlini AA. 2009. High Precision U/Pb Geochronology of Eocene-Miocene South American Land Mammal Ages at Gran Barranca, Argentina. American Geophysical Uniou.

Estrada A. 1984. Resource use by howler monkeys (Alouatta palliata) in the rain forest of Los Tuxtlas, Veracruz, Mexico. Int J Primatol 5:105-131.

Flueck WT, Smith-Flueck JAM. 2013. Severe dental fluorsis in juvenile deer linked to a recent volcanic eruption in Patagonia. J Wildlife Diseases 49:355-366.

Fortelius M. 1985. Ungulate cheek teeth: developmental, functional and evolutionary Interrelations 180:1-76.

Fortelius M, Solounias N. 2000. Functional characterization of ungulate molars using the abrasion-attrition wear gradient: a new method for reconstructing paleodiets. Am Museum Novitates 3301:1-36.

Froehlich JW, Thorington RW, Otis JS. 1981. The demography of Howler Monkeys (Alouatta palliata) on Barro Colorado Island, Panamá. Int J Primatol 2:207-236.

Galbany J, Romero A, Mayo-Alesón M, Itsoma F, Gamarra B, Pérez-Pérez A, Willaume E, Kappeler PM, Charpentier MJE. 2014. Age-related tooth wear differs between forest and Savanna primates. PLOS One.

Genoways HH, Jones JK. 1972. Variation and ecology in a local population of the vesper mouse (Nyctomys sumichrasti).

Goldstein MS. 1948. Dentition of Indian crania from Texas. Am J Phys Anthrop 6:63-84.

Grine FE, Fosse G, Krause DW, Jungers WL. 1986. Analysis of enamel ultrastructure in archaeology; the identification of Ovis Aries and Capra Hircus dental remains. 13:579-595.

Grine FE, Kay RF. 1988. Early hominid diets from a quantitative analysis of dental microwear. Nature 333:765-768.

Hawes JE, Peres JA. 2013. Ecological correlates of trophic status and frugivory in neotropical primates. Oikos.

Hewison AJM, Vincent JP, Angibault JM, Delorme D, Laere GV, Gaillard JM. 1999. Tests of estimation of age from tooth wear on roe deer of known age: variation within and among populations. Can J Zool 77:58-67.

Hillson S. 1987. Teeth. Cambridge: Cambridge University Press.

Hinton RJ. 1981. Form and patterning of anterior tooth wear among aboriginal human groups. Am J Phys Anthropol 54:555-564.

Hodson MJ, White PJ, Mead A, Broadley MR. 2005. Phylogenetic variation in the silicon composition of plants. Ann Bot 96:1027-1046

Hummel J, Findeisen E, Südekum K-H, Ruf I, Kaiser TM, Bucher M, Clauss M, Codron D. 2011. Another one bites the dust: faecal silica levels in large herbivores correlate with high-crowned teeth. Proceedings of the. Royal Society B: Biological Sciences 278:1742-1747.

Ingicco T, Moigne AM, Gommery D. 2012. A deciduous and permanent dental wear stage system for assessing the age of Trachypithecus sp. specimens (Colobinae, Primates). Journal of Archaeological Science 39:421-427.

Janis CM. 1988. An estimation of tooth volume and hypsodonty indices in ungulate mammals, and the correlation of these factors with dietary preference. Mémoires Du Muséum National D'histoire Naturelle, Paris Sér. C 53:367-387.

Janis CM. 1998. Ungulate teeth, diets, and climatic changes at the Eocene/Oligocene boundary. Zoology 100:203-220.

Janis CM, Fortelius M. 1988. On the means whereby mammals achieve increased functional durability of their dentitions, with special reference to limiting factors. Biol Rev 63:197-230.

Karstad L. 1967. Fluorosis in deer (Odocoileus virginianus). J Wildl Dis 3:42-46.

Kay RF. 1981. The nut-crackers: A new theory of the adaptations of the Ramapithecinae. Am J Phys Anthropol 55:141-152.

Kay RF. 2010. A New Primate from the Early Miocene of Gran Barranca, Chubut Province, Argentina: Paleoecological Implications. In: Madden RH, Vucetich G, Carlini AA, and Kay RF, editors. The Paleontology of Gran Barranca: Evolution and Environmental Change through the Middle Cenozoic of Patagonia Cambridge: Cambridge University Press. p 220-239.

Kay RF, Covert HH. 1983. True grit: a microwear experiment. Am J Phys Anthropol 61:33-38. 
Kay RF, Madden R, Vucetich M, Carlini MG, Mazzoni AA, MM Heizler RGH., Sandeman M, H, 1999. Revised age of the Casamayoran South American land Mammals 'Age'- climatic and biotic implications. Proc Natl Acad Sci USA 96:13235-13240.

Kay RF, Williams BA, and Anaya F. 2002. The adaptations of Branisella boliviana, the earliest South American monkey. In: Plavcan JM, van Schaik C, Kay RF, and Jungers WL, editors. Reconstructing Behavior in the Primate Fossil Record. New York: Kluwer Academic/Plenum Publishers. p 339-370.

Kierdorf U, Kierdorf H, Fejerskov O. 1993. Fluoride-induced developmental changes in enamel and dentine of European roe deer (Capreolus capreolus L.) as a result of environmental pollution. Archives of Oral Biology 38:1071-1081.

King SJ, Arrigo-Nelson SJ, Pochron ST, Semprebon GM, Godfrey LR, Wright PC, Jernval J. 2005. Dental senescence in a longlived primate links infant survival to rainfall. Proceedings of the National Academy of Sciences 102:16579-16583.

King SJ, Boyer DM, Tecot S, Strait SG, Zohdy S, Blanco MB, Wright PC, Jernvall J. 2012. Lemur habitat and dental senescence in Ranomafana National Park, Madagascar. Am J Phys Anthropol 148:228-237.

Kutterolf S, Freundt A, Peréz W, Mörz T, Schacht U, Wehrmann H, Schmincke HU. 2008. Pacific offshore record of plinian arc volcanism in Central America: 1. Along-arc correlations. Geochemistry, Geophysics, Geosystems 9:Q02S01-

Kutterolf S, Freundt A, Pérez W, Wehrmann H, and Schmincke HU. 2007. Late Pleistocene to Holocene temporal succession and magnitudes of highly-explosive volcanic eruptions in west-central Nicaragua. Journal of Volcanology and Geothermal Research 163(1,Äi4):55-82.

Larsen CS. 1995. Biological Changes in Human Populations with Agriculture. Annu Rev Anthrop 24:185-213.

Lovejoy CO. 1985. Dental wear in the Libben population: Its functional pattern and role in the determination of adult skeletal age at death. Am J Phys Anthropol 68:47-56.

Lucas P, Constantion P, Wood B, Lawn B. 2008. Dental enamel as a dietary indicator in mammals. Bioessays 30:374-385.

Lucas PW, Omar R, Al-Fadhalah K, Almusallam AS, Henry AG, Michael S, Thai LA, Watzke J, Strait DS, Atkins AG. 2013. Mechanisms and causes of wear in tooth enamel: implications for hominin diets. Journal of the Royal Society Interface 10: 20120923

Lunt DA. 1978. Molar attrition in medieval Danes. Development, function and evolution of teeeth. London: Academic Press. p 465-482.

Madden RH. 2015. Hypsodonty in Mammals: Evolution, Geomorphology, and the role of Earth Surface Processes. Cambridge, UK: Cambridge University Press.

McKee JK, Molnar S. 1988. Measurements of tooth wear among Australian aborigines: II. Intrapopulational variation in patterns of dental attrition. Amer J Phys Anthrop 76:125-136.

Milton K. 1980. The Foraging Strategy of Howler Monkeys: A study in Primate Economics. New York: Columbia University Press.

Molnar S. 1971. Human tooth wear, tooth function and cultural variability. Am J Phys Anthropol 34:175-189.

Molnar S, McKee JK, Molnar IM, Pryzbeck TR. 1983. Tooth wear rates among contemporary Australian Aborigines. J Dent Res 62:562-565.

Morse PE, Daegling DJ, McGraw WS, Pampush JD. 2013. Dental wear among cercopithecid monkeys of the Taï forest, Côte d'Ivoire. Am J Phys Anthropol 150:655-665.

Murphy T. 1959. The changing pattern of dentine exposure in human tooth attrition. Am Journal of Phys Anthropol 17:167-178.

Newman JR, Yu M-H. 1976. Fluorosis in black-tailed deer. J Wildl Dis 12:39-41.

Nussey DH, Metherell B, Moyes K, Donald A, Guinness FE, Clutton-Brock TH. 2007. The relationship between tooth wear, habitat quality and late-life reproduction in a wild red deer population. J Anim Ecol 76:402-412.

Pampush JD, Duque AC, Burrows BR, Daegling DJ, Kenney WF, McGraw WS. 2013. Homoplasy and thick enamel in primates. J Hum Evol 1-9.

Phillips-Conroy JE, Bergman T, and Jolly CJ. 2000. Quantitative assessment of occlusal wear and age estimation in Ethio- pian and Tanzanian baboons. In: Whirehead P, and Jolly CJ, editors. Old World Monkeys. Cambridge UK: Cambridge University Press. p 321-340.

Piperno DR. 1988. Phytolith Analysis: An Archaeological and Geological Perspective. San Diego: Academic Press. 280 p.

Rabenold D, Pearson OM. 2014. Scratching the surface: A critique of Lucas et al. (2013)'s conclusion that phytoliths do not abrade enamel. J Hum E 74:130-133.

Rensberger JM, Von Koenigswald W. 1980. Functional and phyletic interpretation of enamel microstructure in rhinoceroses. Paleobiology 6:477-495.

Riede F, Wheeler JM. 2009. Testing the 'Laacher See hypothesis': tephra as dental abrasive. J Archaeol Sci 36:2384-2391.

Roholm K. 1937. Fluorine intoxication: Nyt Nordisk Forlag.

Romero A, Timm RM. 2013. Reproductive strategies and natural history of the arboreal Neotropical vesper mouse, $\mathrm{Nyc}$ tomys sumichrasti. Mammalia 77:363-370.

Ruffer SA. 1920. Study of abnormalities and pathology of ancient Egyptian teeth. Am J Phys Anthropol 3:335-382.

Sanson GD, Kerr SA, Gross KA. 2007. Do silica phytoliths really wear mammalian teeth? Journal of Archaeological Science 34:526-531.

Schultz AH. 1935. Eruption and decay of the permanent teeth in primates. Am J Phys Anthropol 14:489-581.

Scott RS, Ungar PS, Bergstrom TS, Brown CA, Childs BE, Teaford MF, Walker A. 2006. Dental microwear texture analysis: technical considerations. J Hum E 51:339-349.

Smith J, Genoways H, Jones J. 1977. Cranial and Dental Anomalies in Three Species of Platyhrrhine Monkeys from Nicaragua. Folia Primatol 28:1-42.

Smith P. 1972. Diet and attrition in the Natufians. Amer J Phys Anthrop 37:233-238.

Storey A. 1976. The diet and dentition of new kingdom Pharoahs. Mastication. Bristol: Wright Press.

Strömberg CAE. 2006. Evolution of hypsodonty in equids: testing a hypothesis of adaptation. Paleobiology 32:236-258.

Teaford MF. 1983. Differences in molar wear gradient between adult macaques and langurs. Int J Primatol 4:427-444.

Teaford MF. 1985. Molar microwear and diet in the genus Cebus. Amer J Phys Anthrop 66:363-370.

Teaford MF, and Glander KE. 1996. Dental Microwear and Diet in a Wild Population of Mantled Howling Monkeys (Alouatta palliata). In: Norconk MA, Rosenberger AL, and Garber PA, editors. Adaptive Radiations of Neotropical Primates: Springer US. p 433-449.

Teaford MF, Oyen OJ. 1989. Differences in the rate of molar wear between monkeys raised on different diets. J Dent Res 68:1513-1518.

Teaford MF, Runestad JA. 1992. Dental microwear and diet in Venezuelan primates. Am J Phys Anthropol 88:347-364.

Teaford MF, Tylenda CA. 1991. A New Approach to the Study of Tooth Wear. J Dent Res 70:204-207.

Teaford MF, Walker A. 1984. Quantitative differences in dental microwear between primate species with different diets and a comment on the presumed diet of Sivapithecus. Amer J Phys Anthrop 64:191-200.

Tomenchuk J, Mayhall JT. 1979. A correlation of tooth wear and age among modern Iglooik Eskimos. Am J Phys Anthropol 51:67-77.

Travers CD. 1999. Activity budget. diet, and patterns of resource utilization of the mantled howling monkey (Alouatta palliata) in Ometepe, Nicaragua. Am J Phys Anthropol Abstracts 267.

Ungar PS. 1998. Dental allometry, mporphology, and wear as evidence for diet in fossil primates. Evol Anthropol 6:205-217.

Ungar PS, Teaford MF, Glander KE, Pastor. RF. 1995. Dust Accumulation in the Canopy: A Potential Cause of Dental Microwear in Primates. Am J Phys Anthropol 97:93-99.

Walker A, Hoeck HN, Perez L. 1978. Microwear of mammalian teeth as an indicator of diet. Science 201:908-910.

Walker PL. 1978. A quantitative analysis of dental attrition rates in the Santa Barbara Channel area. Am J Of PhysAnthropol 48:101-106.

Walton KC. 1988. Environmental fluoride and fluorosis in mammals. Mamm Rev 18:77-90. 
Williams SH, Kay RF. 1999. A comparative test of competing adaptive explanations for hypsodonty in ungulates and rodents. Programa Y Resúmenes, Evolución Neotropical Del Cenozoico,La Paz, Bolivia 46-

Williams-Guillén K, Hagell S, Otterstrom S, Spehar S, and Gómez C. 2013. Primate Populations in Fragmented Tropical Dry Forest Landscapes in Southwestern Nicaragua. In: Marsh LK, and Chapman CA, editors. Primates in Fragments: Springer New York. p 105-120.
Xhonga FA, Wolcott RB, Sognnaes RF. 1972. Dental Erosion: II. Clinical Measurements of Dental Erosion Progress. The Journal of the American Dental Association 84:577-582.

Yamada E. 2012. Mesowear Analysis of the Japanese Sika Deer (Cervus nippon) in Different Food Habits: Its Limitations and Applicability. Mammal Study 37:93-103.

Yamashita N. 1998. Functional dental correlates of food properties in five Malagasy lemur species. Am J Phys Anthropol 106:169-188. 